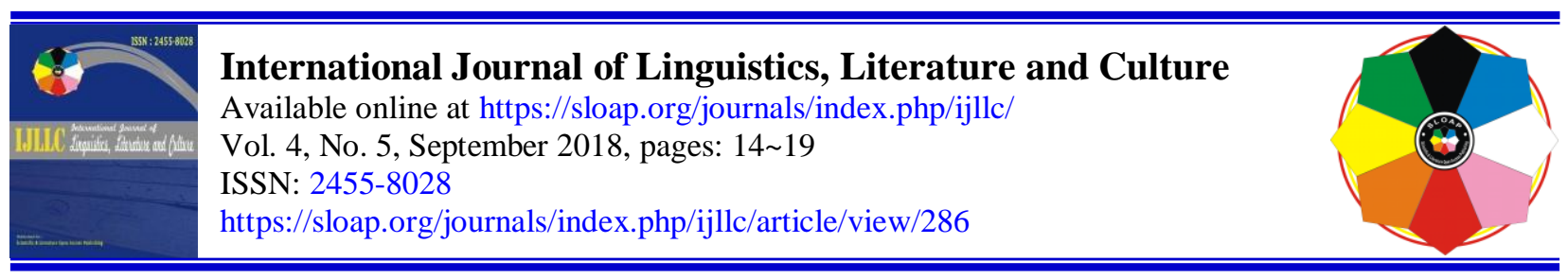

\title{
Kakenauwe of Single Language Prefix
}

Sri Suryana Dinar a

\section{Article history:}

Received: 10 April 2018

Accepted: 1 September 2018

Published: 14 September 2018

\section{Keywords:}

Descriptive;

Kakenauwe;

Language;

Prefix;

Single;

\begin{abstract}
This article discusses the single kakenauwe language prefix. Language is found in Buton district, Southeast Sulawesi Province. The method used in this research is a descriptive method. By using this method, the findings in the study are a single prefix in the language kakenauwe bake-, bako-, ci-, dopo-, fe-, fekhi-, fepe-, fo-, ka-, mem, menci-, mentene -, mo-, na-, nae-, ne, no-, noci-, moko-, nomo-, pa- pisi-, poni-, and sa-.
\end{abstract}

2455-8028 ${ }^{\circledR}$ Copyright 2018. The Author. This is an open-access article under the CC BY-SA license (https://creativecommons.org/licenses/by-sa/4.0/) All rights reserved.

\section{Author correspondence:}

Sri Suryana Dinar,

FKIP Universitas Halu Oleo, Indonesia

Email address: unhalu39@yahoo.co.id

\section{Introduction}

This paper is motivated by the fact that the language of Kakenauwe has not received much attention for research. This language has the function and position as a regional language. Recognizing the importance of the position and function of the regional language in relation to the growth, development, and standardization of the national language as well as the importance of fostering and developing language as one of the elements of culture, the regional languages need to be saved, nurtured, nurtured and developed. As stated by Keraf (1987: 20) in its development, regional languages are still very much needed too, 1) Enrich Indonesian Language, especially in vocabulary and word form, 2) We can recognize various important factors that determine the pattern and structure of society Indonesia, 3) By knowing various aspects of regional languages such as literature, we can recognize the similarity of themes, style of language, and variety of literature. The regional identification factor through language also lays the foundation of national unity and unity and can instill a deep sense of mutual respect (Alkapitani, 2017: Syarifaturrahman, et al., 2017).

The description above suggests that the research of regional languages is very important to realize the documentation. Thus, the function and position do not shift from the actual position. Therefore, the efforts made by various groups, in the study of regional languages scattered in the archipelago, are very beneficial. The intended regional language is one of the regional languages that live and develop in Southeast Sulawesi, namely the language of Kakenauwe.

${ }^{\text {a }}$ FKIP Universitas Halu Oleo, Indonesia 
Literature Review

According to Pateda (1988: 77) in terms of position, affixes can be divided into 5 parts:

a) The prefix is an affix that must be placed in front of a basic morpheme to form words that are displaced in the teachings.

b) Infix is an affix that is placed in the center of the basic morpheme (if the basic morpheme starts with a consonant) to form a word that functions in the utterance.

c) A suffix is an affix placed behind the basic morpheme to form a function in the utterance.

d) Conflict is an affix that must be placed simultaneously on a basic morpheme to form words that function in utterances. For example, [to -, ......] in the rain.

e) Combinations are affixes which consist of two or more which do not need to be attached to form words that function in utterances. For example, [fixing] on the word beautify.

The grouping as mentioned above is in line with the opinion of Keraf (1987: 94-118), that, that words that have affixes can be divided or words that contain prefixes, infixes, suffix, and confixes. In the following description, he also touched on the combination of additions. The explanation of some of the above is as follows:

a) Perfection or prefix is an element that is structurally tied in front of a basic word or basic form.

b) Suffix or suffix is a kind of bound morpheme that is placed behind a basic morpheme. Conflict is a combination of two types of affixes or more which together form a meaning. Traditional grammar treats the confixes as ordinary combinations of prefixes and suffixes, we must eliminate their actual position as a form (morpheme) with a single function and meaning. Combined additions are the use of multiple affixes at once in one basic word, each of which maintains its function and meaning. Infix is a kind of bound morpheme inserted in a word between the first consonant and the first one.

Some of the opinions above are apparently not too far apart from the opinions expressed by Ramlan (1987: 58), among others, as follows:

The affixes located at the front of the lane are called prefix because they are always attached to the front of the base shape, and the ones located in the middle lane are called infixes because they are always attached to the base shape, which is located in the back lane called suffix because they are always attached behind the base shape. These three kinds of affixes are also commonly called prefixes, inserts, and suffixes.

He also added slin from the three kinds of affixes, there are also affixes called separate affixes or simulfix, namely an affix which is attached to one basic form, and supports one function, both semantic and grammatical functions (Syakur, et al., 2018).

\section{Materials and Methods}

The study was classified as field research. Therefore, direct research into the field to obtain research data in accordance with research problems. This research data is in the form of kakenauwe language data used by the language speakers of kakenauwe village, watuwotobe village, kapontori sub-district, buton district.

The method used in this research is a descriptive method. The descriptive method used in this study is mainly directly related to data collection, data assessment, and preparation of research report data. The use of this method aims to make the systematic and accurate description of data (Munawir, 2018: Yani, et al., 2018).

The data of this study are oral language data, in the form of utterances spoken by native speakers of kakenauwe in the village of Watuwotobe, Kapontori sub-district, Buton district. The speeches are in the form of words, phrases and can also be sentenced.

In connection with this study in the form of oral data, the data sources in the study were informants. This informant is a native speaker of the language of Kakenauwe who lives in the village of Watuwotobe, Kapontori District, Buton District. For the data obtained from this study, the main informants were selected from traditional/community leaders and supporting informants came from ordinary people who functioned as complementaries (H Ambo, et al.: 1986).

Dinar, S. S. (2018). Kakenauwe of single language prefix. International Journal of Linguistics, Literature and Culture, 4(5), 14-19. https://doi.org/10.21744/ijllc.v4n5.286 


\section{Results and Analysis}

Kakenauwe's language prefix can play the role of Indonesian, namely the affix which is located at the beginning of the basic form called Prefix or also commonly called the prefix

a) Single

1) Prefix Bake

Bake - + lange 'long' Bakelangke very long' (1.a)

2) Bako Prefix

The Bako prefix - allomorphic possibility of the bake prefix because it has the same basic form and meaning between the two, which forms an adjective and states strongly.

Example:

Bako - + Akho 'hungry Bakoakho very hungry' (2.a)

3) ci- prefix

The ci-prefix in the language of Kakenauwe is one of the affixes that is only capable of adhering to the number

Example:

ci-+ ompulu 'ten' ciompulu 'around ten' (3.a)

4) Dopo Prefix -

Example:

5) fe- prefix

Dopo + kapulu 'machete' 'Dopokapulu' muttering each other '(31.a)

Example:

fe- + wunta 'middle' fewunta 'medium' (4.a)

6) Prefix fekhi-

Example:

fekhi - + wawo 'above' fekhiwawo 'above' (5.a)

7) Fepipe prefix

Example:

Fepé + awi carry 'fepeawi' ask to be carried '(6.b)

8) Prefix fo-

Example:

9) Prefiks ka-

Fo-+ sande 'lean' fosande lean back'(7.a)

Example

ka- $\quad+$ ukhui 'peel' kaukhui 'peller' (8.a)

10) Prefix

Example:

Me- + Takha 'hold' Mentakha 'has the character of being resistant' (9.a)

11) Prefixes menci-

Example:

menci - + a 'weeping' menciae 'often crying' (10.a)

12) Prefix mentene-

Example:

13) Prefix mo-

mentene- + giu 'kinds of 'mentenegiu' various' (11.a)

Example:

mo- + akho 'hungry' moakho feeling hungry '(13.a)

14) Prefixes na-

The na-prefix is the only affix in the language of Kakenauwe which is only able to adhere to the word containing infix -um-, both in verbs and in adjectives.

Example:

$\mathrm{Na}$ - + sumampu ‘down' nasumampu ‘will go down' (14.a) 
15) nae- prefix

Example:

nae- + tolu 'three' naetolu 'three days to come' (15.a)

16) Prefix ne-

Example:

$\mathrm{Ne}-+$ ala 'take' neala 'take' (16.a)

17) prefixes pa-

The prefix pa- the language of Kakenauwe can only be attached to the form of sukhu and teeth. Example:

18) pisi-prefix

Pa- + sukhu urge 'pasukhu' urge'(17.a)

Example:

pisi- + umaa 'eat' pisiumaa 'everyone can eat' (18.a)

19) poni - prefixes

poni-prefix in Kakenauwe can only be attached to the word onto and mustard greens.

Example:

20) sa- prefix

Poni- + onto 'stop' ponionto 'for a moment '(19.a)

Prefix sa-in-language Kakenauwe is very productive because it has the ability to all types of words. However, the affix is the only affix that can only be attached to the word reduplication.

Example:

Sa-+ mai 'come' samai-mai 'always come' (20.a)

21) prefix se-

The prefix se- in Kakenauwe is the same as a prediction in Indonesian, which means one.

Example:

+ mie 'people' semie 'someone' (21.a)

\section{Conclusion}

Based on the results of the above discussion that the language kakenauwe have a single prefix that is bake-, bako, ci-, dopo-, fe-, fekhi-, fepe-, fo-, ka--, menci-, mentene-, mo-, na-, nae-, ne-, no-, noci-, moko-, nomo-, pa- pisi-, poni-, sa-, and seb.

\section{Conflict of interest statement and funding sources}

The authorsdeclared that they have no competing interest. The study was financed by Sri Sryana Dinar

\section{Statement of authorship}

The author(s) have a responsibility for the conception and design of the study. The author(s) have approved the final article.

\section{Acknowledgments}

The author would like to thank the editor of the journal IJLLC for the time given to the author to submit this article, to the rector of Halu Oleo University, Dean of the Faculty of Teacher Training and Educational Sciences for their encouragement to the lecturers to write articles. 


\section{References}

Alkapitani, M. (2017). The enrichment of new vocabularies in Sasak language because of gold mining spreading in Sekotong west Lombok. International Journal of Social Sciences and Humanities (IJSSH), 1(3), 182-193.

H Ambo, G., Ibnu, N., Hamzah, M., \& Lukmanul, H. (1986). Morfologi Kata Kerja Bahasa Wolio.

Keraf, G. (1987). Tata Bahasa Indonesia. Ende Flores. Nusa Inda.

Munawir, M. (2018). The Use of Roi and i'a in Bima Language at District of Sape, Bima: A Sociopragmatics Study (Doctoral dissertation, Universitas Mataram).

Pateda, M. (1988). Linguistik Suatu Pengantar.

Ramlan, S. (1987). A Knotty problem?.

Syakur, A. A., \& Sukri, M. (2018). Text of cigarette advertisement: A semiology study of Roland Barthes. International Journal of Linguistics, Literature and Culture (IJLLC), 4(3), 72-79.

Syarifaturrahman, W. K., \& Hanafi, N. (2017). The Inflection of Sasak Language in Kuripan Village. International Journal of Social Sciences and Humanities (IJSSH), 1(3), 155-181.

Yani, L., Artawa, K., \& Satyawati, N. M. S. (2018). Transitivity construction of verbal clause in Ciacia language. International Journal of Linguistics, Literature and Culture (IJLLC), 4(3), 15-23. 


\section{Biography of Author}

\begin{tabular}{l|l|} 
Sri Suryana Dinar was born in Bulukumba, South Sulawesi on November 1, 1967. He \\
completed his bachelor's degree at the University Halu Oleo in 1992, completed his \\
bachelor degree in 2000 at Hasanuddin University in Makassar. The experience of \\
publication in 2017 wrote in the journal International Journal of Linguistics, Literature \\
and Culture (IJLLC) with the TEAM entitled Survival Wolio Language in Adulthood \\
in Baubau City: Sociolinguistic Study
\end{tabular}

Dinar, S. S. (2018). Kakenauwe of single language prefix. International Journal of Linguistics, Literature and Culture, 4(5), 14-19. https://doi.org/10.21744/ijllc.v4n5.286 